\title{
Socialist political economy with Chinese characteristics in a new era
}

\author{
Yinxing Hong \\ Nanjing University, Nanjing, China \\ China
}

\begin{abstract}
Purpose - The socialist political economy with Chinese characteristics reflects the characteristics of ushering into a new era, and the research object thereof shifts to productive forces. Emancipating and developing productive forces and achieving common prosperity become the main theme. Wealth supersedes value as the fundamental category of economic analysis.

Design/methodology/approach - The theoretical system of socialist political economy with Chinese characteristics cannot proceed from transcendental theories but is problem-oriented. Leading problems involve development stages and research-level problems.

Findings - The economic operation analysis is subject to the goal of optimal allocation of resources with micro-level analysis focused on efficiency and macro-level analysis focused on economic growth and macroeconomic stability also known as economic security. The economic development analysis explores the laws of development and related development concepts in compliance with laws of productive forces. The new development concepts i.e. the innovative coordinated green open and shared development drive the innovation of development theory in political economy.

Originality/value - Accordingly, the political economy cannot study the system only, but also needs to study the problems of economic operation and economic development. Therefore, the theoretical system of the political economy tends to encompass three major parts, namely economic system, economic operation and economic development (including foreign economy). The basic economic system analysis needs to understand the relationship between public ownership and non-public ownership, between distribution according to work and factor payments, and between socialism and market economy from the perspective of coexistence theory, thus transforming institutional advantage into governance advantage.
\end{abstract}

Keywords New era, Socialism with Chinese characteristics, Political economy

Paper type Research paper

Theories originate from practice and guide practice in turn. An important goal of building a theoretical system of the socialist political economy with Chinese characteristics is to enhance its theoretical guidance, and the prerequisite is to boost the explanatory power of theory for practice. At the National Symposium on the Work of Philosophy and Social Sciences on May 17, 2016, Xi Jinping, the general secretary of CPC Central Committee, pointed out that the study of Chinese philosophy and social sciences should center on what we are doing and tap new material, identify new problems, present new ideas and build new theories from the practice of China's reform and development. This is the guiding principle of constructing the socialist political economy with Chinese characteristics that enjoy theoretical guidance and

(C) Management World. Published in China Political Economy. Published by Emerald Publishing Limited. This article is published under the Creative Commons Attribution (CC BY 4.0) licence. Anyone may reproduce, distribute, translate and create derivative works of this article (for both commercial and noncommercial purposes), subject to full attribution to the original publication and authors. The full terms of this licence may be seen at http://creativecommons.org/licences/by/4.0/legalcode. Originally published in Simplified Chinese in Economic Research Journal.

This article is the phased result of "Research on Basic Theoretical Problems of Economics with Chinese Characteristics in the New Era" (18VXK002), a major special research project headed by the author under the National Social Science Fund of China. 
CPE

3,2

explanatory power of practice. To establish a systematic economy with Chinese manner, Chinese style and Chinese characteristics, we should focus on the following three aspects: First, we should tell Chinese stories and theorize and systemize economic thoughts and ideas that have successfully guided China's economic development. Second, although political economy is a theoretical discipline, it must serve practical purposes and need to make innovations on research, including the object, levels and methods of research, to reflect the characteristics of entry into a new era. Third, the political economy with Chinese characteristics should be known to the world besides being recognized within China.

\section{The object and mainline of research of socialist political economy with Chinese characteristics}

Marxist political economy is a science that analyzes productive forces and production relations, so the object and mainline of research of political economy concern an era. Therefore, the political economy has distinct characteristics of the times. Ever since its founding by Karl Marx, the political economy has enjoyed the features of the times. In the face of capitalism under analysis, its mission is to overturn that society. Therefore, the political economy's research object is production relations, and its mainline is to reveal that the capitalist production relations hinder the development of productive forces. In the early years of New China (i.e. the People's Republic of China), in order to solve the issue how socialism defeats capitalism, the political economy still focused on production relations as its object of study in a relatively long period, and its mainline was the superiority of socialist production relations. As a result, the political economy remained the economics of criticism and struggle in a fairly long period.

Since the Third Plenary Session of the 11th Central Committee of the Communist Party of China in 1978, the Party's central work has shifted to economic construction, thus starting a new process of constructing socialism with Chinese characteristics. Based on the characteristics of the primary stage of socialism, Deng Xiaoping indicated that "the nature of socialism is to emancipate productive forces, develop productive forces, abolish exploitation, eliminate polarization, and finally achieve common prosperity." This shows that the socialism with Chinese characteristics has two major goals: emancipating and developing productive forces and achieving common prosperity, which has a decisive impact on the research object and mainline of the socialist political economy with Chinese characteristics.

The socialist political economy with Chinese characteristics is a political economy in the new era. The following points shall be noted in determining its research object and mainline:

First, close attention needs to be paid to productive forces when it comes to the research object of the socialist political economy. As Karl Marx made clear in The Communist Manifesto, the task after the proletariat seizes power is: "to increase the total quantity of productive forces as quickly as possible" (Marx, 2009a, p. 52). In particular, the reason why Chinese socialism is in the primary stage is that the productivity level fails to reach that of developed capitalist countries. Therefore, at the primary stage of socialism, if the object of political economy does not enter into the field of productive forces, the research scope and field of political economy will narrow and the explanatory power and guiding role for the Chinese economy will lessen, which would make it difficult for the political economy to guide the process of socialism with Chinese characteristics scientifically.

Second, what do productive forces under the research of political economy mean? There used to be a long-running popular view in academia that the factors of productive forces are the three simple factors in the process of labor stated by Karl Marx in Das Kapital, which are labor, subject of labor, and means of labor. Now it appears that the defect of this definition is its inability to fully reflect the factors required to boost productive forces. People's educator Wei (2015) once argued that this three-factor generalization deviates from the relevant 
Marxist discussion. He put forward a theory of "multiple factors of productive forces" based on Karl Marx's idea in Das Kapital that the factors to boost labor productivity include "average skill degree of workers, development level of science and degree of the application of science in technology, social integration of production process, scale and efficiency of means of production, and natural conditions" (Marx, 2004a, p. 53). For the socialist political economy with Chinese characteristics, the research on productive forces is focused on the social layer rather than the technical layer. Science, division of labor, management, and natural force are all factors of productive forces. In particular, in the new era, with the progress of science and technology, the internet, big data, and artificial intelligence are gradually integrated into the process of developing productivity. An important task of political economy research is to mobilize all productive forces to develop productivity.

Third, what layers do the productive forces in the research of political economy contain? Deng Xiaoping stressed that we cannot merely talk about developing productive forces - both emancipation and development of productive forces are essential. While presiding over the sixth collective learning session of the Political Bureau of the CPC Central Committee, Xi Jinping, general secretary of CPC Central Committee stressed, “... we should firmly establish the concept that protecting ecological environment means protecting productive forces, and improving ecological environment means developing productive forces." Based on this, the socialist political economy with Chinese characteristics has three levels of productive forces: First, the emancipation of productive forces, which involves the adjustment of production relations and reform of the economic system conducive to the development of productive forces. Second, the development of productive forces, which involves the mobilization and coordination of all factors of productive forces. Third, the protection of productive forces, which involves the protection and improvement of environment and ecology. The construction of a theoretical system of the socialist political economy with Chinese characteristics is all about establishing a systematic economic theory of emancipating, developing, and protecting productive forces.

Fourth, the goal of developing productive forces is to satisfy people's yearning for a better life. Shortly after the reform and opening-up, China made clear that the principal contradiction facing Chinese society is the one between the ever-growing material and cultural needs of the people and the low level of social production. Therefore, China stated that the main task of socialism at its primary stage was to develop social productive forces, to change the backwardness of social production, and to make the people rich and build a comprehensive well-off society. Given that the socialism with Chinese characteristics has entered the new era, the principal contradiction facing Chinese society has evolved to the contradiction between the people's ever-growing needs for a better life and the unbalanced and inadequate development. The so-called needs for a better life not only involve the needs for a better life at the material and cultural level but also involve the ever-growing needs for a better life at higher levels, including democracy, the rule of law, fairness, justice, security and environment. The constraint on satisfying people's needs for a better life is unbalanced and inadequate development. Facing the principal social contradiction in the new era, the development of productive forces shall focus on addressing unbalanced and inadequate development that fails to meet people's needs for a better life, which involves development quality, efficiency and structure.

The ultimate aim of developing productive forces is to achieve common prosperity, which is the essential requirement of socialism. After the start of reform and opening-up, in order to make the people get rich as quickly as possible, China used to implement the policy of allowing some people to get rich first and created a path in which people who get rich first should help the poor and finally common prosperity will be realized. Now the comprehensive well-off society is about to be realized, and the people become much richer than ever before, but their income gap further widens. The issue of unbalanced development to be addressed in the new era involves narrowing the income gap and achieving common prosperity. The gist of the concept of shared development put forward by Xi Jinping is to share the benefits of development, seek further development via 
CPE

3,2

262

sharing, and work hard to ensure all-people sharing, all-round sharing, and co-construction and co-sharing of the fruits of reform and development. In the shared development, people will share the fruits of reform and development, continually receive tangible benefits, enjoy a greater sense of gain from improved livelihood and gradually achieve common prosperity.

Of course, the designation of productive forces as the research object of the socialist political economy with Chinese characteristics does not mean there is no need to study production relations, just like the study of production relations cannot do without productive forces. Chinese development issues cannot be addressed without the analysis of production relations, and only the political economy studies both production relations and productive forces. Only the theory generated based on the analysis of both production relations and productive forces can provide accurate guidance for China's economic development, especially on the need to leverage the institutional advantage of socialist economy to drive economic development. It is worth noting that although the reform should not be entangled in the distinction of "what is socialism and what is capitalism," the political economy needs to distinguish socialism from capitalism and public ownership from non-public ownership because it is part of the function of the political economy as a discipline. However, the purpose of drawing a clear distinction between public ownership and non-public ownership is not to solve the issue who defeats whom but to make sure that public and non-public ownership sectors of the economy can compete and develop on an equal footing based on their own strengths, subject to the general requirement of developing productive forces.

Based on the foregoing definition of the object and mainline of the research, the socialist political economy with Chinese characteristics not just tells socialism from capitalism in terms of production relations, but also provides basic economic theories. The political economy is a science of studying the law of economic operation and economic development under certain socioeconomic relations, and the economic theories generated thereon are theoretical generalizations of the actual socialist economic system and economic development path with Chinese characteristics and should be included in the theoretical system of socialist political economy with Chinese characteristics in the making. Those theories provide basic economic knowledge accordingly. To account for the confidence in the system, path, theories and culture of socialism at the level of economic theory is the responsibility of the political economy. In addition to its role as ideological education material, the political economy is also expected to provide theoretical economic guidance for China's economic decision-making and policy formulation. In China, the mainstream economics must be the political economy. The reason why it is the mainstream economics is that it is expected to provide theoretical guidance for the national economic decisions, economic development and economic reform by employing the principles of the political economy.

\section{Wealth becomes the fundamental category of economic analysis}

At the Third Plenary Session of the 18th Central Committee of the CPC, Xi Jinping, general secretary of CPC Central Committee, was quoted as saying, "We should deepen the reform to unleash all the vitality contained in work, knowledge, technology, management, and capital and give full play to all sources of social wealth" (Xi, 2014), which clearly establishes the critical position of wealth as the fundamental category and the research of sources of wealth creation in the socialist political economy with Chinese characteristics. At the present stage of socialism, economic construction becomes the central task, increasing social wealth becomes the goal of the socialist political economy with Chinese characteristics, and promoting full development of the sources of wealth creation will become a research task of the socialist political economy with Chinese characteristics.

The political economy represented by Das Kapital not only provides the value creation theory but provides the wealth creation theory. According to Karl Marx's analysis, a 
commodity is a unity of use-value and value. Wealth falls within the category of use-value. In accordance with Karl Marx's definition of wealth and value, whether the political economy lays emphasis on value analysis or wealth analysis depends on the goal and task of the political economy. Although the economic principles revealed by the labor theory of value is still applicable to socialist economic analysis, especially the analysis of the market economy, the value theory is obviously insufficient for the socialist economic analysis aimed at increasing national wealth. The importance of wealth category and wealth analysis can be seen in Karl Marx's distinction between value and wealth.

The fundamental category of Marxist political-economic analysis of the capitalist economy is value. Based on the scientific labor theory of value, Karl Marx not only makes clear that labor is the only source of value creation but also reveals that the surplus-value created by living labor is occupied by capitalists for free. He thus discovers that the proletariat is the gravedigger of the capitalist society and concludes that capitalism is doomed to be superseded by socialism. Therefore, the process of value analysis is also a process of revealing various contradictions of the capitalist society. As China now enters into the new era of building the new society, the goal of the political economy analysis is to construct this society and identify the constructors of this society. Based on this analysis target, the theories of wealth category and wealth creation are especially needed.

In accordance with the theory of Marxist political economy, the wealth category of the socialist political economy with Chinese characteristics has the following requirements: First, wealth is use-value. "Regardless of the social form of wealth, the use-value always constitutes the material content of wealth" (Marx, 2004a). Second, wealth is the aggregate social product. Value and wealth are different. The value of a product includes transferred old value $(C)$ and newly created value $(V+M)$. $V+M$ means the value created by living labor and is also what Karl Marx calls value product. According to value analysis, $C$ is transfer value and not newly created value. However, wealth analysis attaches great importance to the role of $C$ in wealth creation. $C$ is part of the wealth, and the newly created wealth is the sum of $C+V+M$. As the material condition of labor, $C$ plays an important role in wealth creation. Third, accumulated capital is the increase in social wealth, which is the source of social expanded reproduction. According to Marx, "The larger social wealth or functional capital is, the bigger the scale and capacity of wealth growth" (Marx, 2004b). The law of capitalistic accumulation is the polarization between the accumulation of wealth and the accumulation of poverty. After we enter into a socialist society, we still need to accumulate social wealth through capital accumulation for expanded reproduction. We do so for seeking the benefits for all the people and satisfying their ever-growing material and cultural needs. Fourth, the form of wealth. The earliest form of wealth is material wealth. In modern society, the service, which used to be a luxury of the capitalists in the Marx's time, becomes a necessity of ordinary people. At that time, Karl Marx even predicted that free time would be an important measure of wealth in future society. Shortened labor time can save time and create the means for everyone so individuals could develop themselves in various aspects like art and science. As the age of industrial civilization evolves to the age of ecological civilization, just like Xi Jinping, general secretary of CPC Central Committee, states that "lucid waters and lush mountains are invaluable assets," clean water, fresh air, great biodiversity, and green environment are precious ecological wealth. This view of wealth reflects a harmonious coexistence between humans and nature. Therefore, the forms of wealth expand from material wealth to service wealth, spiritual wealth, and ecological wealth.

Based on the foregoing wealth concepts, the socialist political economy with Chinese characteristics needs to establish a people-centered outlook on wealth: First, it is made clear that the purpose of increasing wealth is to improve the people's well-being, and we need to create more wealth to satisfy the people's needs for a better life, including the growth of public wealth and household wealth. Second, we should identify the source and driving force of 
CPE

3,2

264

wealth increase. We should not only know the factors of wealth creation but also clearly understand the significance of capital accumulation to wealth growth, that is, capital accumulation is the source of expanded reproduction. On this basis, the inclusion of wealth analysis in the socialist political economy with Chinese characteristics will drive theoretical innovation in various aspects.

First, unlike the fact that labor is the only source of value creation, the wealth creation process is the labor process itself. Labor cannot create wealth alone, and it can create wealth only if it works with other factors. The factors of wealth creation include, without limitation, labor, capital, land, technology and management. In particular, with scientific and technological progress, the factors other than labor will play an increasingly large role in wealth creation and directly influence labor productivity. Therefore, wealth analysis needs to study all factors of wealth creation, their syntagmatic relationship in wealth creation and their historical features and dynamic integration relationships in the changes of mode of production. From the perspective of wealth creation, modern society is something like what Karl Marx describes: “. . . with the development of great industry, the creation of real wealth depends less on labor time and amount of labor expended but depends more on. . . the average level of science and technical progress, or say, the application of such science in production" (Marx, 2009b). In particular, "with such development of great industry, direct labor itself is no longer the basis of production, because direct labor becomes an activity of supervision and regulation, and moreover, a product is no longer the result of individual direct labor - it is usually the result of the integration of social activities of producers" (Marx, 2009b). In Karl Marx's opinion, "the use of labor time as the measure of wealth shows that the wealth is built upon poverty per se" (Marx, 2009b). This conclusion is very important for seeking the driving forces of development in the new era.

Second, as the sources of value are not the same with those of wealth, value distribution and wealth distribution also differ. Value distribution refers to the distribution of newly created value between necessary labor value and surplus-value, and the splitting of surplusvalue among capitalists. Because wealth creation is the result of the combination of factors including labor, land, capital, technology and management, wealth distribution refers to the distribution of wealth among all factor owners involved in wealth creation according to their respective contribution to wealth. Among others, the labor juxtaposed with capital, technology and management refers to direct labor. Factors like technology, management and data are also labor and belong to what Karl Marx calls complex labor. According to Marx (2004c, p. 58), relatively complex labor counts as "multiples of simple labor," and therefore, a small amount of complex labor equals to a large amount of simple labor (Marx, 2004c). Wealth growth calls for the full flow of all factors of wealth creation and requires all factor owners to do their best in their proper places. The notion that "contributions are evaluated by market and determine rewards" put forward at the Fourth Plenary Session of the 19th Central Committee of the $\mathrm{CPC}$ reflects an objective evaluation of factor payments. The resulting distribution shares of various factors are not an issue who exploits whom, but whoever contributes most is entitled to the biggest share. This principle of fairness is consistent with the efficiency goal of resource allocation and the efficiency principle of factor combination. Its effect is to unleash all the vitality of various factors, including labor, capital, technology, and management, in wealth creation and cause social wealth to surge, just like what Karl Marx expected.

Third, criteria for evaluating productivity. When value is used to evaluate productivity, no matter how productive forces change, the value created remains unchanged within the same labor time. In particular, when it comes to the evaluation of productivity of science and technology, the value theory only indicates that the first producer to adopt advanced technology has higher labor productivity than other producers. As Karl Marx once stated, "The labor with higher productivity plays the role of square labor, or say, it creates more 
value than the same type of average social labor within the same time... Compared with other capitalists in the same industry, the capitalist adopting an improved mode of production can occupy a higher portion of surplus labor within a working day" (Marx, 2004d). However, once the improved technology is adopted by the whole society, such excess surplusvalue will disappear. The situation will differ if wealth is used as a criterion for evaluating productivity. Marxist wealth analysis finds that a productive force is the productive force of concrete labor, and productivity is measured by the use-value created within the same labor time. As Karl Marx said, "There is a huge difference between the value of products made by a British worker using a powerful automatic machine in a week and the value of products made by a Chinese worker using a spinning wheel in a week. The British worker can spin hundreds of pounds of cotton within the same time as the Chinese worker spins one pound of cotton" (Marx, 2004e). Obviously, the contribution of science and technology herein is not measured by the amount of value but by the amount of use-value or amount of wealth. Therefore, "the mission given to science is: to become a means of wealth generation for people to get rich" (Marx, 2009c). It has been impossible to fully evaluate the value of science and technology from the perspective of labor value. Wealth analysis can accurately evaluate the value of science and technology as a productive force. The judgment that science technology is the primary productive force is an evaluation based on wealth analysis.

The foregoing distinctions between wealth and value all involve major issues in the political economy. The socialist political economy with Chinese characteristics regards wealth as a fundamental economic category and lays emphasis on wealth analysis, and the corresponding theoretical and practical value of wealth and wealth analysis cannot be replaced by value category and value analysis. That wealth analysis runs throughout the socialist political economy with Chinese characteristics means that emancipating, developing and protecting productive forces is the process of wealth growth. The production, exchange, distribution and consumption under the research of political economy is the production, exchange, distribution and consumption of wealth. The analyses of system, economic operation and economic development in political economy are all aimed to promote wealth growth.

\section{The problem orientation drives theoretic innovation of political economy}

Adhering to problem orientation is a distinctive feature of Marxism, and the research of the real socialist economy with Chinese characteristics in a problem-oriented fashion means that we should not only proceed from reality but also come back to reality and solve actual problems, which is the source and basis of theoretical innovation. Only in this way can we boost the ability of political economy theories to interpret reality and guide economic practices.

It is a well-targeted approach that the socialist political economy with Chinese characteristics advocates problem orientation. First, problem orientation can break away from the apriorism orientation. The practice of proceeding from a priori theories to demonstrate $a$ priori theories can lead to dogmas that are divorced from reality and cannot explain actual economic problems. Second, problem orientation can overcome model orientation. Model orientation has emerged in recent years, and model analysis is actually a methodological approach - the researchers set up a model, collect data, and make deductions before arriving at an obvious conclusion. As a kind of abstract analysis based on mathematical models, model orientation is not focused on theoretical innovation targeted at real economic problems. There were a number of scholars who published their papers on international journals by employing Western economics paradigm, general mathematical models and Chinese data. This kind of research is actually still under the framework of Western economics and cannot be regarded as the economics with Chinese characteristics 
$\mathrm{CPE}$

3,2

266

but the case application of Western economics in China. The socialist political economy with Chinese characteristics does not completely exclude the model analysis method but denies model orientation. What we need is theoretical innovations oriented towards major reform and development issues. And the reason is quite simple: What China needs at the present stage is common prosperity that could address the basic living needs of the Chinese people.

Problem orientation is closely related to theoretical innovation. Problems are the starting point and also the driving force of innovation. For the socialist political economy with Chinese characteristics, what is the leading problem? It is the problem of the times. Theoretical innovation cannot be driven unless we listen to the voice of the times, respond to the call of the times, and carefully study how to solve critical and pressing problems in the relevant era. The political economy has distinct characteristics of the times at each period, which is relevant to the theoretical requirement at each period. Since the Third Plenary Session of the 11th Central Committee of the Communist Party of China, the Party's central work has shifted to economic construction. From Deng Xiaoping's notion that development is of overriding importance to $\mathrm{Xi}$ Jinping's notion that development is the key task of governance for the rejuvenation of the Chinese nation, the socialist political economy with Chinese characteristics guided by such ideologue highlights the "development" characteristic. In the new era, staged development problems call for innovation of major theoretical issues in the political economy.

The first issue is the orientation towards principal contradiction facing the society in the new era, which involves the contradiction between the level of productive forces and social needs. The political economy at each period has distinct characteristics of that time. It is relevant to the theoretical requirement at each period. Although China is still in the primary stage of socialism and will remain so for a long time to come, socialism with Chinese characteristics has entered a new era and transitioned from the state of getting rich to the state of getting strong. The principal contradiction facing Chinese society has evolved to the contradiction between unbalanced and inadequate development and the people's evergrowing needs for a better life. The constraint on satisfying the people's needs for a better life is unbalanced and inadequate development. Under the principal contradiction facing Chinese society in the new era, solving the problem of principal contradiction becomes the direction of theoretical innovation, that is, addressing the problem of unbalanced and inadequate development which leads to the failure of satisfying the people's needs for a better life becomes a key research subject of the political economy.

The second issue is the orientation towards the issues of high-quality economic development. Thanks to its sustained high-speed economic growth for over 30 years since the reform and opening-up, China is now the world's second-largest economy, and its economic development level evolved from the low-income stage to the upper-middle stage. With highspeed growth over so many years, potential growth factors have been fully unleashed, which is mainly manifested as follows: low-cost labor supply supported by surplus labor reduces significantly; population dividends supporting high investment and high savings decrease remarkably; unsustainable development of the supply of material factors becomes increasingly prominent; bottleneck constraints on energy, resources and environment are restricting economic growth. As a result, the development problems emerge: traditional development impetus reliant upon resource investment declines and the resource supply by the environment reaches the limit; the economic structure is seriously unbalanced; the development quality of the industry at the lower end of the global value chain is low; and the widening income gap results in the people's low sense of gain from economic development. Against such background, economic development has to shift from high-speed growth to high-quality development. Relevant major theoretic issues of the political economy are about the transformation of economic growth pattern and high-quality development, which involves not only institutional innovation but also theoretical innovation on economic operation and development. 
The further issue of problem orientation is the innovation of the theoretical system of socialist political economy with Chinese characteristics. Is it possible to build a theoretical system by imitating the abstract analysis method in Das Kapital? It requires us to study whether the objective conditions of the abstract method in Das Kapital are still applicable at the present stage.

First, the research method mentioned by Karl Marx has two paths: one is the research method from the concrete to the abstract and the other is the narrative method from the abstract to the concrete. He used commodity, the most essential category abstracted out, as the starting point of his works and established a well-knit theoretical system step by step by following the logic from the abstract to the concrete. During the research of a real socialist economy, we cannot analyze the present socialist economy by abstracting out a fundamental category most similar to the commodity like Das Kapital analyzes capitalism. That is because the socialist economy at the primary stage is an immatured social form that remains to be further developed and improved.

Second, during the analysis of the capitalist society, Karl Marx abstracted out the dominant capitalist production relations from various production relations. As Karl Marx said, "In all social forms, there is always a form of production that determines the position and influence of all other forms of production, and the corresponding production relation dominates the position and influence of all other production relations. It is like the ubiquitous light that covers all other colors and changes their characteristics" (Marx, 1995). Regarding the production relations at the primary stage of socialism, not only that public ownership is the mainstay and various economic entities of non-public ownership thrive, but also that the mixture of diverse forms of ownership becomes a realization form of the basic economic system. In this context, the public sector of the economy cannot become the "ubiquitous light" covering the color of other forms of ownership. Therefore, the research of socialist political economy with Chinese characteristics on production relations cannot be restricted to research on public ownership. The non-public sector of the economy and mixed-ownership economy should also become the research object of the political economy.

In this way, for the discipline system construction of the political economy, problem orientation involves the issues at research level. Problem orientation raises the issue of the explanatory power of the socialist political economy with Chinese characteristics to interpret the actual economy. So-called interpreting actual economy means conducting theoretical analyses of real problems instead of going too deep into abstract concepts.

The analysis of an economy generally involves four aspects: First, production relations, i.e. the economic system. Second, economic operation, i.e. allocation of resources. Third, economic development, i.e. research on the transition from backwardness to the state of modernization. Fourth, the foreign economy. It seems that a division of work has long existed in the economics disciplines: for example, political economy for production relations, Western economics for economic operation issues, and development economics, which is also chiefly Western, for economic development. Therefore, the political economy contains nothing but a few dull and dry principle stipulations and dogmas on production relations. It has been found that this kind of disciplinary division of work is not accurate. When Karl Marx founded the political economy, he made a six-book plan (capital, landed property, wage-labor, state, foreign trade, world market). It can be seen that the political economy involves a wide range of subjects, from system analysis to economic operation and development analysis. Das Kapital is the first volume in Karl Marx's six-book plan, which means Das Kapital should not be regarded as the whole of Marxist political economy.

Since the socialist political economy with Chinese characteristics is the economics centered on economic construction, all of the above four aspects shall be analyzed. It is necessary not only to study the nature and law of socialist economic relations, expound the definitive property of the nature of the socialist economic system and point out the inevitable 
CPE

3,2

268

trend that socialism will supersede capitalism and evolve to communism, but also to propose the theories of economic operation under the socialist market economy condition and the theories of economic development aimed at building a great modern socialist country. In the new era, economic globalization interweaves with the reversion of globalization and the Chinese economy needs to develop in an open environment. Therefore, the world's economic issues also become China's economic issues. The economic operation, economic development, foreign economy and system analysis form an indivisible whole. Among them, major theoretical problems involved in economic system analysis are the three aspects of the basic economic system, i.e. public ownership as the mainstay, common development of economic entities under diverse forms of ownership, and socialist market economy. Major theoretic problems involved in economic operation analysis are economic operation efficiency and national security issues. The major theoretic problem involved in economic development analysis is the whole process of integrating new development concepts into economic development. The theoretical problem involved in foreign economic analysis is the issue of developing the Chinese economy in the community with a shared future for mankind.

\section{System analysis focusing on the advantages of China's basic economic system} There is no doubt that the research of socialist political economy with Chinese characteristics starts from the analysis of the basic economic system, in which the public ownership is the mainstay and economic entities under diverse forms of ownership develop together, distribution according to work is dominant and a variety of modes of distribution coexist, and the socialist market economy constitutes the basic economic system of socialism from three aspects, i.e. production, distribution and exchange. In accordance with Deng Xiaoping's statement on the essence of socialism, the institutional advantage of the basic economic system of socialism is that the system reflects the essential requirement of socialism in all aspects: The common development of economic entities under diverse forms of ownership, the coexistence of a variety of modes of distribution, and the market economy reflect the development level of social productivity at the primary stage of socialism, and they emancipate and develop productive forces institutionally. Public ownership as the mainstay, distribution according to work as the main body, and the combination of socialism and market economy reflect the institutional requirements of socialism and highlight the superiority of the socialist system in terms of eliminating polarization and finally achieving common prosperity.

In every above aspect, the socialist basic economic system involves institutional arrangements in fields that were considered to be opposed in the past, such as public and nonpublic sectors of the economy, distribution according to work and factor payments, and socialism and market economy. Factors of non-public ownership, factor payments and market economy unleashed by market-oriented reform contribute considerably to economic development; however, people tend to try all means to restrict the relationship between these mentioned factors with public ownership, distribution according to work and socialism based on the opposition theory. After the basic economic system of socialism is confirmed, it is necessary to understand the institutional coexistence of the two fields based on the coexistence theory. Only in this way can the institutional advantages of the basic economic system be fully shown.

We may understand the institutional advantage of the economic system in which public ownership is the mainstay and economic entities of diverse ownership develop together from the perspective of the coexistence theory. First, the development of economic entities under diverse forms of ownership mobilizes all resources and vitality necessary for developing productivity, especially the introduction of foreign investment and the rapid growth of private investment. Regarding private economy, more than $90 \%$ of all enterprises in China 
are now private enterprises, which contribute over $50 \%$ of tax revenue, over $60 \%$ of China's gross domestic product, more than $70 \%$ of technology innovation results in China, and more than $80 \%$ of jobs in urban areas. With the deepening of reform, the fields and scope of private economy are widening, which breaks the dogma that private economy can only enter into the fields of which the level of socialization is low; instead, private enterprises can operate in competitive fields to the extent of their competitiveness and are now entering into key sectors of the national economy and fields of public welfare. Second, unlike the non-public sector mainly in competitive fields and pursuing profit goals, public sector is mainly active in public welfare and natural monopoly fields. Although the public sector has requirements of efficiency, it is more focused on public welfare goals. That public ownership is the mainstay no longer means that public-owned enterprises are in a dominant position; instead, it means that public assets have advantages among the total social assets (both in terms of quality and quantity) and state-owned economy controls the lifelines of the national economy. The Stateowned economy can reflect the concept of people-centered development institutionally, carry out the fairness and justice requirement of socialism, and enable all the people to share the fruits of development. Third, competition among economic entities under diverse forms of ownership impels the state-owned economy to reform its own system with entry and exit mechanism, improves the realization form of public ownership and thus enhances the competitiveness, creativity, control and anti-risk capability of the public sector of economy. Obviously, although the public and non-public sectors of economy compete with each other, they can develop well and give play to their institutional advantages in the fields where they prove highly competitive.

We may understand the institutional advantage of distribution according to work as the main body and coexistence of various modes of distribution mode from the perspective of the coexistence theory. The coexistence of all distribution modes is intended to unleash the vitality contained in work, knowledge, technology, management, capital and data that create wealth, fully releasing the potential of economic development and meanwhile promoting the efforts to get rich through hard work and gradually achieve common prosperity. The realization form of this distribution system is the mechanism in which all production factors participate in income distribution. Its content includes: First, the principles on which factors including labor, capital, technology and management participate in income distribution, that is, based on input, contribution, and market supply and demand. And at the Fourth Plenary Session of the 19th Central Committee of the CPC, this principle was summarized as: the market evaluates the contribution, and the contribution determines rewards, which shows the efficiency principle of distribution. Does the participation of production factors in income distribution conflict with the distribution according to work as the main body? The point is scientific judgment on the connotation and denotation of income distribution according to work. The labor income, one of the factors participating in income distribution, does not merely refer to the income of laborers at the frontline of production, namely directly labor income. In fact, technology and management, two other factors participating in income distribution, are also labor income. According to Karl Marx's definition of "total productive labor," the labor of technical and managerial personnel belongs to total productive labor. The income they earn is also labor rewards. The rewards for technology and management factors are rewards for complex labor. If this portion of labor rewards is recognized and included in total labor rewards, distribution according to work as the main body should be guaranteed.

We may understand the institutional advantage of integrating socialism with market economy from the perspective of the coexistence theory. At the initial stage of the marketoriented reform, the economics community (especially foreign economics community) has a dogma that public ownership cannot integrate with market economy. However, China's market-oriented reform broke this dogma and realized an organic integration of socialist 
CPE

3,2 economic system and market economy in the field of ownership. First, the public sector of economy is defined as public assets, including state-owned assets and collective assets. On this basis, it is made clear that public ownership can be realized in multiple forms and that joint-stock enterprise is a major realization form of public ownership. In this way, state-owned enterprises are restructured and its integration with market economy is realized. Second, in the reform of the relationship between government and business, on the one hand, the separation of government administration from enterprise management is realized, separating government functions from the functions of public-owned enterprises; on the other hand, the separation of government administration from state-owned assets management is implemented, where the management of state-owned assets by China shifts from enterprise management to assets management and then to capital management. Therefore, the institutional barrier for the integration of public-owned enterprises with market economy is eliminated. As Mr. Xi Jinping pointed out, with the reform over years, state-owned enterprises have been generally integrated with market economy. Third, the socialist market economy means the combination of letting the market determine resource allocation and giving better play to government role. Both sides perform their duties and coordinate with each other.

Obviously, the relationship between those two institutional arrangements included in basic economic system explained from the coexistence theory is not the opposing relationship of a zero-sum game, but the one where each arrangement gives play to its advantages. Therefore, there is no need to restrict which, let alone argue which is superior. The issue that should be further studied is how to transform the institutional advantage of the socialist basic economic system into actual governance advantage, and the key is to solve the issue on its realization forms. This mean that the economic system analysis cannot rest on the analysis of the basic economic system, and the research has to expand to an analysis of its realization forms.

The main realization form of the basic economic system in which public ownership is the mainstay and economic entities of diverse ownership develop together is mixed ownership, which is represented by the joint-stock system. The essence of mixed ownership is that various forms of ownership develop jointly within an enterprise. Mixed ownership is based on the modern system of property rights. The property right theory is the development of the ownership theory. The role of enterprises as market entities is not only to operate independently and be responsible for their profits and losses, but also to become the entity of property rights. For any enterprise, the most fatal risk is loss of property rights and the most important income is the appreciation of assets. Keeping people's efforts in economic activities closely linked to property rights is a steady, persistent incentive. The modern system of property rights not only requires clear ownership of property rights, so as to make clear the gains and losses of property rights, but also makes property right incentive the most powerful driver of the market economy. Definition, allocation and circulation of property rights tie people's efforts in economic activities closely to property rights, which is a steady, persistent incentive. The 19th National Congress of the CPC put forward that improving the property rights system needs to highlight the role of property rights as an effective incentive, that is, providing property right incentives and mechanisms to boost the vitality of various types of enterprises and make state-owned capital and private capital larger, stronger and better. State-owned assets management shall shift its focus to capital management. In addition, the property rights system has its structural issues, such as the separation of investors' property rights from legal person property rights in the joint-stock system and the separation of ownership, contracting right and management rights in the rural land system. All these institutional arrangements further enlarge the institutional advantages of ownership arrangement.

The main realization form of distribution according to work as the mainstay with the coexistence of various distribution modes is that all factors participate in income distribution. 
The key is the following two institutional arrangements: On the one hand, the principle that all production factors participate in income distribution is expressly stated. To be specific, the market evaluates the contribution of all factors, and contribution determines factor payment. This promotes an effective combination of factors by enterprises, boosts total factor productivity and also pushes up the supply of excellent factors that contribute largely. On the other hand, the frontline laborers' income shall be increased based on the requirement of distribution according to work as the mainstay. And this requirement may be satisfied through three rounds of distribution: At the stage of primary distribution, we should properly handle the relationship between equity and efficiency, increase the proportion of labor rewards in primary distribution and cause labor rewards to grow with the improvement of labor productivity; at the redistribution stage, we should go further about equity by perfecting such redistribution mechanisms as taxation, social security and transfer payment; we should pay more attention to the role of the third distribution, develop charity and other social welfare programs, and establish the mechanism in which the rich offer to help the poor to get rich. Besides, we should increase factor supply to directly laborers by beefing up the investment in human capital of laborers and increasing residents' property income through diverse channels to enable laborers to own non-labor production factors and secure income from non-labor factors, which further proves the compatibility of factor payment with distribution according to work.

The realization form of the socialist market economy involves economic operation, which will be elaborated in the following section.

\section{Economic operation analysis focusing on efficiency and balance}

Economic system analysis is the starting point of economic operation analysis. The task of the political economy in analyzing economic operation is to identify the specific forms of the economic system according to the economic law revealed. Subject to the goal of optimal resource allocation, micro-level analysis of economic operation focuses on efficiency, while macro-level analysis focuses on economic growth and macroeconomic balance.

There are generally two Chinese practices driving the establishment and development of the economic operation theory in the socialist political economy with Chinese characteristics, namely the recognition of socialist market economy and the supply-side structural reform. The former clarifies the institutional context of economic operation, and the latter clarifies the necessity of solving quality, efficiency, and structural problems at the supply side and seeking new growth drivers. For this end, the research of political economy on the economic operation is mainly focused on the following four aspects:

First, define the economic operational efficiency goal from the perspectives of factor allocation and combination. As Xi Jinping put it, “... we should optimize the current allocation and combination of production factors, boost the utilization levels of production factors, promote the improvement of total factor productivity and continually strengthen the endogenous drivers of economic growth." (Xi, 2017a) Marx's theory has a number of factor productivity concepts, such as labor productivity, land productivity, and capital productivity. The total factor productivity, which was first put forward by Robert Solow, a winner of the Nobel Prize in economics, means that the sum of the productivity generated by the combination of all factors is greater than the sum of the productivity generated by factor inputs individually. The fact that the idea of total factor productivity has been introduced into the socialist political economy with Chinese characteristics and used as the goal of economic operation indicates the openness of the socialist political economy with Chinese characteristics and the correct application of the Western economic concept. The decisive role of the market in driving the growth of total factor productivity not only lies in the fact that the market determines the flow direction of resources (e.g. sectors, enterprises), but also 
CPE

3,2

272

lies in the fact that the market determines the combination of all factors (resources). The aggregation of all factors in enterprises and industries is guided by the prices determined by supply-demand relationship on various factor markets to evolve to the most efficient combination of factors. Such combination of factors calls for the corresponding distribution mode. Its effect is that all production factors are utilized in the most effective manner and the total factor productivity is thereby increased.

Second, seek the drivers of economic operation from both supply and demand sides. Xi Jinping once said, "Supply and demand are two basic aspects of internal relations of market economy, and their relationship is the dialectical relationship of unity of opposites. Each side cannot exist without the other. They are interdependent and mutually conditional" and "Supply side and demand side are two basic means to manage and regulate macro economy" (Xi, 2017b). Demand side management aims at solving total quantity problems and lays emphasis on short-term regulation. Make clear the effect of consumption, investment and export to drive economic growth jointly on the demand side, which is the mechanism of driving macroeconomic growth after a shift to the market economy. Among others, special attention should be paid to the fundamental role of consumption in economic development. Supply-side management aims at solving structural problems and lays emphasis on longterm development. The ultimate aim of supply-side structural reform is to satisfy demands, its main direction is to improve supply quality, and the fundamental approach is to deepen the reform. We shall not only solve the structural problem featuring the coexistence of insufficient effective supply and excessive ineffective capacities, but also solve the problem of lack of supply-side impetus. Unlike demand side stressing market selection, the supply side emphasizes economic incentive, especially incentives for market entities: First, to reduce the burden of taxes, fees, interest and society on enterprises, reduce business costs, and let enterprises compete on market with less burden; second, to protect the properties of entrepreneurs and encourage entrepreneurial spirit.

Third, study the economic regulation mechanism by analyzing the relationship between government and market. The relationship between government and market is the core content of the economic system reform and also the core content of the political economy research on economic regulation mechanism. Market regulation means the allocation of resources based on market rules, market prices and market competition for achieving benefit maximization and efficiency optimization. Government role does not just lie in overcoming market failures in such aspects as polarization, externalities and macroeconomic disequilibrium, but also lies in reflecting institutional requirements of socialism, guaranteeing stable economic growth and macro-variables equilibrium during the operations of market economy. Therefore, the economic regulation mechanism to be established is the synergy between strong government and strong market, which generally involves institutional arrangement in two aspects: First, a reasonable range of macro economy shall be defined so as to offer sufficient space for market regulation of resource allocation. Accordingly, macro control shall shift to range-based regulation in order to prevent systematic macro risks through countercyclical regulation. The reasonable range demonstrated by the political economy means that the leading macroeconomic indicator ranges between the upper limit of unemployment rate and the lower limit of inflation rate. Range-based regulation determines the "upper limit" and "lower limit" of economic operation by combining three key macroeconomic indicators, namely economic growth rate, inflation rate and unemployment rate. We should maintain the "lower limit" of stable growth and employment and the "upper limit" of preventing inflation and concentrate on economic restructuring and transformation. Second, to ensure that the market allocates resources effectively, it is necessary to improve the market mechanism by constructing a high-standard market system, improving the fairness competition system, and building a law-based business environment. Also, all kinds of market entities should enter into all kinds of markets 
equally and acquire production factors equally. Free flows of factors, enterprises, products and services should be realized. Market rules should be fair, open and transparent.

Fourth, handle the relationship between the fictitious economy and the real economy properly. Fictitious economy is speculative economy built on fictitious capital. Real economy is the foundation of any country. The economy of any country is ultimately supported by real economy, and the wealth of any country is realized through the growth of real economy. According to Marx's fictitious capital theory, fictitious economy is derived from real economy and serves real economy. Fictitious economy provides investors with an investment selection mechanism, thus offering a channel for entry into real economy. For example, bank credit serving real economy directly is not fictitious economy, while utilizing credit mechanism for speculation is fictitious economy; enterprises issuing shares to raise funds is not fictitious economy, while using shares to speculate on stock market is fictitious economy; buying homes for residence is not fictitious economy, while buying homes for speculation is fictitious economy; using foreign exchange for import and export is not fictitious economy, while using foreign exchange for speculation arbitrage is fictitious economy. Modern economy cannot do without fictitious economy. At the present stage of economic development, the scope of fictitious capital expands greatly. Capitalizable income includes not only bonds and stocks mentioned by Karl Marx at that time but also foreign exchange and financial derivatives like financial futures, stock indexes and options. They are indicative factors of modern economic progress and modern economic conflicts and crises as well. Economic cycle can be largely explained by inflation and deflation of fictitious economy. Excessive speculation in fictitious economy may lead to the possibility that more and more capital will not be directly invested in real economy but invested in speculative markets, such as stock market, foreign exchange market and real estate market. As a consequence, capital investment in real economy sector is seriously inadequate, while excessive investment on speculative markets leads to bubble economy. At the present stage, the biggest impact on real economy is fictitious economy. The trend of shifting from real economy to fictitious economy will cause the economy to lose its anchor. From the perspective of supply-side structural reform, the revitalization of real economy shall proceed from the following two points: First, make sure that real economy receives adequate investment. Second, offer sufficient incentives to enterprises in real economy, especially the efforts to reduce their operating costs.

\section{Economic development analysis reflecting new development concepts}

Developing the economy is developing productive forces. The study of socialist political economy with Chinese characteristics on economic development is to develop productive forces, laws of main development and related development concepts following the laws of productive forces. The law that economic development should follow in the new era is "development must be scientific development following economic laws and sustainable development following natural laws" (Xi, 2017c), as pointed out by Xi Jinping. The development concepts are the concepts of innovation, coordination, green, openness, and sharing proposed by $\mathrm{Xi}$. The core issue of developing countries' development is modernization. The development theory in political economy should not only proceed from reality but also reflect the features of China's system. After building a well-off society in an all-round way in 2020, China will immediately enter the stage of the construction of modernization. The development theory to be generated under this background is modernization theory established based on the new development concepts.

First, study the goal of modernization based on the concept of shared development. Compared with a well-off society in an all-round way, modernization is not a simple change in quantitative evaluation indicators, but a qualitative improvement, which involves setting the goal and frame of reference of modernization and determining the primary evaluation index 
CPE

3,2

274

of modernization. The modernization theory contributed by political economy embodies the people-centered development view. Modernization refers to entering the modern growth stage, which roughly includes the modernization of science and technology, the economic structure, and people. According to the two-step modernization program, the basic realization of modernization is to make people more affluent, and when modernization is fully realized, people will be happier and healthier. Common prosperity is the main feature of socialist modernization with Chinese characteristics. In the stage of modernization basically realized, the gaps of development and residents' living standards between urban and rural areas have narrowed significantly, and in the stage of modernization fully realized, the common prosperity of all people will be realized basically. Therefore, socialist modernization is sharing the fruits of development of modernization and can effectively avoid the "middleincome trap."

Second, study the modernization strategy based on the concept of innovation-driven development. Innovation is the first motive force of development. Innovation drive is not only to solve the problem of efficiency but also to realize the new combination of factors by intangible factors, which is the application and diffusion of scientific and technological achievements in production and commerce and the creation of new growth factors. The core technology is the country's pillar of great power. Under the background of global value chain competition, it is necessary not only to encourage free exploration and innovation but also to clarify the national goal orientation of innovation and deploy innovation chain around the industrial chain. Under the new scientific and technological revolution, the source of technological innovation has turned to new breakthroughs in science and technology from universities and academies of science. Knowledge capital and human capital play a decisive role in innovation-driven and modern economic growth. It is necessary to pay attention to the transformation of scientific and technological achievements, the connection and integration of knowledge innovation and technological innovation, and the deep integration of production, education and research has become the focus of innovative research.

Third, study the road to modernization based on the concept of green development. Western developed countries were in the era of industrial civilization when they promoted modernization, and the supply of resources was relatively loose. These countries could support their extensive modernization by freely discharging and plundering foreign resources. The consequence of this is what Xi Jinping argues, “. . It has only been more than 300 years since the beginning of industrial civilization, the huge productivity of human society has created the western modernization of a few developed countries, but it has threatened the survival of mankind and the continuation of life on Earth" (Xi, 2013). The modernization in the new era is the modernization in the era of ecological civilization, and the current environment of resources is not like the previous environment. Therefore, China's modernization road needs to change from high consumption and high pollution to green development. The modernization to be built is one in which man and nature coexist harmoniously. It is necessary to provide more high-quality ecological products to meet people's growing needs for a beautiful ecological environment while creating more material wealth and spiritual wealth to meet people's growing needs for a better life.

Fourth, study the modernization of the dual social urban-rural structure based on the concept of coordinated development. The modernization issue of the dual social urban-rural structure is the fundamental issue of development. The tasks of industrialization and urbanization in the conventional sense have been basically completed after the entry of the new era. To address the modernization issue of the dual social urban-rural structure, we need to strengthen the weak areas in agricultural modernization and urbanization (citizenization) of people who have moved to cities from rural areas, which is a vital field to achieve coordinated development. As far as developing the weakness in agricultural modernization, the existing development of agriculture, farmers and rural area in China is to solve the three 
rural issues by non-agriculturalization, that is, utilizing non-agriculturalization to solve the agricultural issues, urbanization to solve rural areas issues and citizenship to solve farmers' issues. For promoting agriculture modernization and realizing a strong agriculture industry, it is necessary to build a high-quality and efficient modern agricultural industry system that is compatible with the rapid upgrading of residents' consumption and to increase agricultural total factor productivity. For promoting farmer modernization and realizing their wealth, it is necessary not only to enrich the pockets (material achievements) of the farmers but also the minds (spiritual achievements) of the farmers. For promoting rural modernization and realizing beautiful countryside, we should build beautiful rural areas on the basis of developing green agriculture and ecological agriculture. Rural revitalization needs to focus on addressing the fundamental revitalization issues, that is, the revitalization of industry, talents, culture, ecology and organization. When it comes to new urbanization, there are two new contents: First, promote the urbanization of people, with emphasis on citizenization, which not only means the transfer of population into cities but also requires that farmers who stay in rural areas can enjoy equal civil rights with urban people. Second, promote the factors of urban development into the countryside to realize the deeply integrative development of urban and rural areas and realize the urbanization of cities and towns.

Lastly, study opening to the outside world based on the concept of open development. In modern society, the economic development of any country has its international background. Under the background of economic globalization and China's 40-years opening up, China needs to upgrade from opening-up to open development and undergo two important transformations correspondingly: One is to build a community with a shared future for mankind and participate in global economic governance and the other is to combine the opening-up with improving economic development level and enhancing international competitiveness to build a domestic demand-oriented, open economy. In this way, compared with the existing opening-up policy, the open development will be further developed as follows: First, the export-oriented and foreign investment-oriented approach shifts to equal stress on import and export as well as the attraction of foreign capital and investments abroad. Second, participating in the global economy shifts from highlighting the comparative advantages of resources and labor to seeking competitive advantages. It is a new open-up strategy that cultivating international competitive advantage to improve open-up efficiency. Third, the priority of foreign factors to be introduced changes from material factors to factors of innovation. An important feature of modern economic growth is the extensive use of the worldwide stock of technology and knowledge. China mainly introduced foreign advanced technology by introducing foreign capital previously and implements an innovation-driven development strategy currently, and the focus of China's introduction of foreign resources shifts to international factors of innovation, especially high-end innovative talents while the core of China's international cooperation shifts to technology cooperation. Fourth, the policy of opening up should be combined with the strategic basis of expanding domestic demand, including expanding the domestic demand market that is open to the outside world. The scope of foreign investment access should be expanded from manufacturing to financial, educational, cultural, medical and other service sectors. Fifth, establish a new open economic system on a larger scale and at a higher level, which involves the comprehensive opening of financial, foreign trade, foreign exchange and other systems and the institutional improvement of the marketization of RMB exchange rate, the free exchange of RMB, the international flow of capital and other institutional construction, and pilot free trade zones should become the carrier of building a new open economic system.

Based on the above new ideas of economic development in the new era, the action to start modernization is to build a modern economic system, in which the economic system related to economic development involves an innovation-driven industrial system with coordinated development; urban and rural regional development system that highlights strengths and 
CPE 3,2

joint coordination; resource-saving, eco-friendly, green development system; and a multibalanced, safe, efficient, fully opening-up system. These will become the major contents of political economy and economic development theory.

\section{References}

Marx, K. (1995), "An introduction to the Critique of political economy", in The Central Compilation and Translation Bureau (Ed.), Makesi Engesi Xuanji [Collected Works of Marx and Engels] (Chinese Edition), People's Publishing House, Beijing, Vol. 2, p. 24.

Marx, K. (2004a), "The two factors of a commodity: use-value and value", in The Central Compilation and Translation Bureau (Ed.), Das Kapital (Chinese Edition), People's Publishing House, Beijing, Vol. 1, p. 53, 49.

Marx, K. (2004b), "Different forms of the relative surplus population. The general law of capitalistic accumulation", in The Central Compilation and Translation Bureau (Ed.), Das Kapital (Chinese Edition), People's Publishing House, Beijing, Vol. 1, p. 742.

Marx, K. (2004c), "The Two-fold character of the labour embodied in Commodities", in The Central Compilation and Translation Bureau (Ed.), Das Kapital (Chinese Edition), People's Publishing House, Beijing, Vol. 1, p. 58.

Marx, K. (2004d), "The concept of relative surplus value", in The Central Compilation and Translation Bureau (Ed.), Das Kapital (Chinese Edition), People's Publishing House, Beijing, Vol. 1, p. 370.

Marx, K. (2004e), "Circumstances that, independently of the proportional division of surplus-value into capital and revenue, determine the amount of accumulation. Degree of exploitation of labourpower. Productivity of labour. Growing difference in amount between capital employed and capital consumed. Magnitude of capital advanced", in The Central Compilation and Translation Bureau (Ed.), Das Kapital (Chinese Edition), People's Publishing House, Beijing, Vol. 1, p. 699.

Marx, K. (2009a), "The communist manifesto", in The Central Compilation and Translation Bureau (Ed.), Makesi Engesi Wenji [Collected Works of Marx and Engels] (Chinese Edition), People's Publishing House, Beijing, p. 52.

Marx, K. (2009b), "Machine system and scientific development and the change of capitalist labour process", in The Central Compilation and Translation Bureau (Ed.), Makesi Engesi Wenji [Marx and Engels Collected Works] (Chinese Edition), People's Publishing House, Beijing, Vol. 8, p. 200, 195.

Marx, K. (2009c), "Machine, factory system, worker conditions", in The Central Compilation and Translation Bureau (Ed.), Makesi Engesi Wenji [Marx and Engels Collected Works] (Chinese Edition), People's Publishing House, Beijing, Vol. 8, p. 356.

Wei, X.H. (2015), Zhongguo Tese Shehuizhuyi Jingji Lilun Tixi Yanjiu [Research on Theory System of Socialist Economy with Chinese Characteristics], Zhongguo caizheng jingji chubanshe [China Financial \& Economic Publishing House], Beijing.

Xi, J.P. (2013), Zhijiang Xinyu, Zhejiang People's Publishing House, Hangzhou, p. 119.

Xi, J.P. (2014), Xi Jinping Tan Zhiguo Lizheng [Xi Jinping: The Governance of China], Foreign Languages Press, Beijing, p. 93.

Xi, J.P. (2017a), "Speech at the end of the inspection in Qinghai Province (excerpt) (August 24, 2016)", in Party Literature Research Center of the CPC Central Committee (Ed.), Xi Jinping Guanyu Shehuizhuyi Jingii Jianshe Lunshu Zhaibian [Compilation of Xi's Remarks on Socialist Economic Construction], Central Party Literature Press, Beijing, p. 108.

$\mathrm{Xi}$, J.P. (2017b), "Speech at the special seminar on the study and implementation of the spirit of the Fifth Plenary Session of the 18th CPC Central Committee by major leading cadres at the provincial and ministerial level (January 18, 2016)", in Party Literature Research Center of the CPC Central Committee (Ed.), Xi Jinping Guanyu Shehuizhuyi Jingji Jianshe Lunshu Zhaibian 
[Compilation of Xi's Remarks on Socialist Economic Construction], Central Party Literature Press, Beijing, p. 99.

Xi, J.P. (2017c), "Speech at the symposium of experts on the economic situation (July 8, 2014)", in Party Literature Research Center of the CPC Central Committee (Ed.), Xi Jinping Guanyu Shehuizhuyi Jingji Jianshe Lunshu Zhaibian [Compilation of Xi's Remarks on Socialist Economic Construction], Central Party Literature Press, Beijing, p. 320.

\section{Further reading}

Wei, X.H. (2019), "Zhongguo tese shehuizhuyi zhengzhi jingiixue de zhuxian he luoji qidian" [The mainline and logical starting point of socialist political economy with Chinese characteristics], available at: http://paper.people.com.cn/rmrb/page/2019-10/14/09/rmrb2019101409.pdf (accessed 8 October 2020).

\section{Corresponding author}

Yinxing Hong can be contacted at: yinxing@nju.edu.cn

For instructions on how to order reprints of this article, please visit our website:

www.emeraldgrouppublishing.com/licensing/reprints.htm

Or contact us for further details: permissions@emeraldinsight.com 